\title{
Pengendalian Kualitas Produk Billet Baja KS1008 Di PT Krakatau Steel, Cilegon Menggunakan Grafik Kendali Max-MEWMA
}

\author{
${ }^{1}$ Tb. Elgi Faturahman S, ${ }^{2}$ Muhammad Mashuri, ${ }^{3} \mathrm{Ni}$ Luh Putu Satyaning Pradnya Paramitha \\ Departemen Statistika, Fakultas Matematika, Komputasi dan Sains Data, \\ Institut Teknologi Sepuluh Nopember (ITS) \\ J1. Arief Rahman Hakim, Surabaya 60111 Indonesia \\ E-mail: 1'elgifsy@gmail.com, ${ }^{2}$ m_mashuri@statistika.its.ac.id, ${ }^{3}$ sat.pradnyaparamita@gmail.com
}

\begin{abstract}
Abstrak - Industri baja sebagai industri strategis yang digunakan sebagai bahan baku penting bagi industri-industri secara keseluruhan. PT Krakatau Steel merupakan produsen baja terpadu yang pertama di Indonesia dan menjadi pemimpin pasar di industri baja dalam negeri. Unit produksi yang menjadi fokus penelitian ini adalah pabrik billet baja. Pada penelitian ini digunakan grafik kendali Max-MEWMA. Hasil grafik kendali Max-MEWMA pada fase satu telah terkendali secara statistik pada iterasi 3 setelah menghilangkan 11 pengamatan sehingga dilanjutkan pada pengendalian fase dua. Pada penerapan fase dua grafik kendali belum terkendali secara statistik. Mangan (Mn) merupakan variabel yang berkontribusi besar dalam menyebabkan pengamatan out of control pada penelitian ini. Dengan diperkuat dengan 6 faktor penyebab utama proses produksi billet baja KS1008 tidak terkendali secara statistik. Kapabilitas dengan indeks $M_{p}$ kinerja proses produksi billet baja KS1008 potensi sudah baik dan mencapai ragam atau sebaran yang diinginkan Perusahaan, sedangkan dengan menggunakan indeks $M_{p k}$ secara multivariat proses memiliki aktual yang rendah sehingga kinerja proses produksi billet baja di PT Krakatau Steel tidak kapabel.
\end{abstract}

Kata Kunci- Analisis kapabilitas, Billet Baja, Grafik kendali Max-MEWMA, Pengendalian Kualitas

\section{PENDAHULUAN}

$\mathrm{D}_{\mathrm{p}}^{\mathrm{n}}$ unia industri memegang peran penting dalam era pembangunan di Indonesia. Munculnya industri kecil dan besar baik perusahaan swasta maupun perusahaan negara akan menjadi tonggak dalam memajukan bangsa. Hanya perusahaan yang mempunyai daya saing yang tinggi yang dapat bertahan di dalam usaha meningkatkan keuntungan. Dalam dunia perindustrian kualitas atau mutu produk dan produktivitas adalah kunci keberhasilan bagi berbagai sistem produksi. Kualitas dapat diartikan sebagai tingkat atau ukuran kesesuaian suatu produk dengan pemakainya, kualitas diartikan sebagai tingkat kesesuaian produk dengan standar yang telah ditetapkan [1]. Kualitas dari suatu produk yang dihasilkan oleh suatu perusahaan ditentukan berdasarkan ukuran-ukuran dan karakteristik tertentu. Indonesia termasuk salah satu konsumen sekaligus produsen baja yang besar. Berdasarkan data Kementrian Perindustrian, industri logam dasar besi dan baja Indonesia tumbuh sebesar $12,74 \%$ pada semester I tahun 2012 dan saat ini konsumsi baja di Indonesia mencapai 12,54 juta ton.

PT Krakatau Steel merupakan produsen baja terpadu yang pertama di Indonesia dan menjadi pemimpin pasar di industri baja dalam Negeri. Perusahaan ini memiliki enam unit produksi. Unit produksi yang menjadi fokus penelitian ini adalah unit produksi pada pabrik billet baja. Dalam penelitian ini, akan dilakukan pengendalian kualitas secara statistik pada billet baja karbon rendah dengan grade KS1008 melalui grafik kendali. Dari 10 variabel pengukuran yang diuji secara rutin, akan digunakan 3 variabel utama dalam komposisi billet baja KS1008 antara lain Karbon (C), Silicon (Si), Mangan (Mn). Komposisi kimia tersebut sangat berpengaruh terhadap sifat mekanis dari produk yang dihasilkan dan memiliki hubungan satu sama lain secara kimiawi [2]. Sehingga ketika setting formula pada pabrik dilakukan, jika kandungan Karbon (C) dinaikkan maka akan mengurangi kandungan pada Mangan (Mn) dan Silicon (Si) kemudian jika kandungan Mangan (Mn) dan Silicon (Si) dinaikkan makan akan meningkatkan kandungan pada Karbon (C) sehingga antar variabel teridentifikasi saling berhubungann, maka dari itu digunakan grafik kendali multivariat yang lebih sensitif dalam mendeteksi pergeseran proses secara multivariat. Selain itu, berdasarkan data dari perusahaan mengalami pergeseran proses yang relatif kecil yaitu $0,3 \sigma, 0,002 \sigma$, dan $0,62 \sigma$ sehingga digunakan grafik kendali Max-MEWMA yang lebih sensitif dalam mendeteksi pergeseran proses kecil secara multivariat. Sehingga menghasilkan produk yang berkualitas serta sesuai spesifikasi. Oleh karena itu, perlu dilakukan identifikasi sinyal out of control pada setiap variabel penelitian. Maka dari itu dilakukan identifikasi sinyal out of control menggunakan grafik kendali MaxMEWMA untuk setiap pasangan dua variabel dan menggunakan diagram ishikawa untuk mengetahui penyebab pengamatan yang out of control

Data pengamatan yang digunakan diambil pada bulan Oktober 2017 sampai bulan April 2018 menggunakan dua fase dengan tujuan monitoring pergeseran mean sekaligus varians proses menggunakan grafik kendali MaxMEWMA, menganalisis kapabalitas untuk mengukur kemampuan proses produksi billet baja KS1008 dan mengidentifikasi penyebab terjadinya kecacatan. Penelitian ini diharapkan dapat menjadi masukan bagi PT. Krakatau Steel dalam memonitor dan meningkatkan kualitas produknya khususnya billet baja KS1008 diwaktu yang akan datang.

\section{TINJAUAN PUSTAKA}

\section{A. Uji Dependensi Antar Variabel}

Metode bartlett test akan digunakan untuk menguji korelasi antar karakteristik kualitas ini. Uji Bartlett Sphericity merupakan pengujian yang digunakan untuk mengetahui apakah matrik korelasi sama dengan matrik identitas, serta untuk mengetahui apakah terdapat hubungan (korelasi) antar variabel. Hipotesis dan statistik uji dari pengujian korelasi yang digunakan adalah sebagai berikut $[3]$.

$\mathrm{H}_{0}: \boldsymbol{\rho}=\boldsymbol{I}$ (tidak ada korelasi antar karakteristik kualitas)

$\mathrm{H}_{1}: \boldsymbol{\rho} \neq \boldsymbol{I}$ (terdapat korelasi antar karakteristik kualitas)

Statistik uji:

$$
\chi^{2}=-\left(m-1-\frac{2 p+5}{6}\right) \ln |\boldsymbol{R}|,
$$

di mana:

$m \quad$ : jumlah observasi $(i=1,2, \ldots, m)$

$p \quad:$ jumlah karakteristik kualitas $(j=1,2, \ldots, p)$

$\mathbf{R} \quad$ : matrik korelasi dari masing-masing karakteristik kualitas

$|\mathbf{R}| \quad$ : determinan matrik korelasi 
Dari hipotesis dan statistik uji diatas, dapat diketahui bahwa daerah penolakan $H_{0}$ yaitu apabila nilai $\chi^{2} \geq$ $\chi_{\left(\alpha, \frac{1}{2} p(p-1)\right)}^{2}$ pada taraf signifikansi $\alpha$ atau $p$-value $<\alpha$ sehingga dapat disimpulkan bahwa terdapat hubungan antar variabel.

\section{B. Uji Distribusi Normal Multivariat}

Pengujian normal multivariat dilakukan untuk mengetahui data hasil pengamatan mengikuti distribusi normal atau tidak. Suatu pengamatan $\mathrm{X}_{1}, \mathrm{X}_{2}, \ldots, \mathrm{X}_{\mathrm{P}}$ berdistribusi normal multivariat dengan parameter $\mu$ dan $\Sigma$ jika memiliki fungsi densitas sebagai berikut [4].

$$
f(X)=\frac{1}{(2 \pi)^{p / 2}|\Sigma|^{1 / 2}} e^{-\frac{1}{2}(X-\mu)^{T} \Sigma^{-1}(X-\mu)}
$$

Pengujian disribusi normal multivariat dilakukan dengan pengujian Saphiro Wilks menggunakan hipotesis sebagai berikut [5].

$H_{0}: F(x)=F_{w^{*}}(x)$ (Data berdistribusi normal multivariat) $H_{1}: F(x) \neq F_{w^{*}}(x) \quad$ (Data tidak berdistribusi normal multivariat)

Statistik uji:

$$
W^{*}=\frac{1}{p} \sum_{i=1}^{p} W_{Z_{i}}
$$

Dengan $W_{Z_{i}}$ adalah statistik Shapiro-Wilk berdasarkan observasi ke-i dari pengamatan tranformasi $Z_{i 1}, \ldots, Z_{\text {in }}, i=$ $1, \ldots, p$. Variabel dikatakan mengikuti distribusi normal multivariat jika nilai statistik uji mendekati 1 , sebaliknya jika nilai statistik uji kecil atau jauh dari 1 maka dikatakan tidak mengikuti distribusi normal multivariat. Selain itu data dapat dikatakan berdistribusi normal multivariat jika $p$ value $>\alpha$ pada tingkat signifikansi $\alpha$.

C. Grafik Kendali Max-MEWMA

Dalam metode ini, asumsi bahwa sebuah proses terdiri dari karakteristik kualitas $k$ dilambangkan dengan $\mathrm{X}$, dengan $\mathrm{X} \sim \mathrm{N}_{k}\left(\mu, \sum\right)$ dan $\mathrm{X}_{i 2}, \ldots, \mathrm{X}_{i n}, i=1,2, \ldots, \mathrm{i}$ adalah ukuran sampel $n$ yang dibuat dari proses. Misalkan $\mu_{0}$ dan $\sum_{0}$ menjadi vektor rata-rata dan matriks kovarian yang diinginkan masing-masing. Kami mengasumsikan bahwa vector acak $\mathrm{X}_{i j}$ tidak saling tergantung satu sama lain, baik di dalam sampel dan di antara sampel.

Pertama, mempertimbangkan untuk memantau vektor rata-rata proses. Misal $\overline{\mathrm{X}}_{i}=n^{-1} \sum_{j=1}^{n} \mathrm{X}_{i j}$ menjadi vector rata-rata sampel. Didefinisikan sebagai berikut.

$$
\boldsymbol{Z}_{\boldsymbol{i}}=(1-\lambda) \boldsymbol{Z}_{i-1}+\lambda\left(\overline{\mathbf{X}}_{\boldsymbol{i}}-\boldsymbol{\mu}_{\mathbf{0}}\right)
$$

dengan $Z_{0}$ adalah titik awal dan $\mu_{0}$ adalah vektor rata-rata sampel total. $\lambda$ adalah smoothing parameter yang bernilai 0 $\leq \lambda \leq 1$. Ketika $Z_{0}=\mu-\mu_{0}$. Kemudian sebagai berikut.

$$
E\left(\boldsymbol{Z}_{i}\right)=\boldsymbol{\mu}-\boldsymbol{\mu}_{\mathbf{0}}
$$

dan

$$
\operatorname{Cov}\left(\boldsymbol{Z}_{i}\right)=\frac{\lambda\left[1-(1-\lambda)^{2 i}\right]}{n(2-\lambda)} \sum
$$

karena itu,

$$
\boldsymbol{Z}_{i} \sim N_{k}\left(\boldsymbol{\mu}-\boldsymbol{\mu}_{\mathbf{0}}, \operatorname{Cov}\left(\boldsymbol{Z}_{i}\right)\right)
$$

dan

$$
T_{i}=\frac{n(2-\lambda)}{\lambda\left[1-(1-\lambda)^{2 i}\right]} \boldsymbol{Z}_{i}^{\prime} \Sigma^{-1} \boldsymbol{Z}_{\boldsymbol{i}} \sim X_{k, \delta^{2}}^{2}
$$

dengan $\operatorname{Cov}($.$) adalah fungsi covarians dari sebuah distribusi$ multivariat, $\sum^{-1}$ adalah invers dari $\sum$, dan $k$ dan $\delta^{2}$ masingmasing merupakan derajat kebebasan dan parameter non centrality dari non central distribusi chi-square dengan $\delta^{2}=$ $\left\{\frac{n}{2-\lambda}\left[\lambda\left[1-(1-\lambda)^{2 i}\right]\right]\right\}\left(\mu-\mu_{0}\right)^{\prime} \Sigma^{-1}\left(\mu-\mu_{0}\right)$.

Statistik untuk memantau proses vector rata-rata didefinisikan sebagai berikut.

$$
U_{i}=\phi^{-1}\left[H_{k}\left\{\frac{n(2-\lambda)}{\lambda\left[1-(1-\lambda)^{2 i}\right]} Z_{i}^{\prime} \sum_{\mathbf{0}}^{-1} Z_{i}\right\}\right]
$$

dengan $H_{k}($.$) adalah fungsi distribusi chi-square dengan k$ adalah derajat kebebasan. $\phi($.$) adalah fungsi distribusi$ normal standar dan $\phi^{-1}$ adalah invers dari $\phi($.$) . Untuk$ memantau proses variabilitas, didefinisikan sebagai berikut.

$$
W_{i}=\sum_{j=1}^{n}\left(\boldsymbol{X}_{\boldsymbol{i} j}-\overline{\boldsymbol{X}}_{\boldsymbol{i}}\right)^{\prime} \sum_{\mathbf{0}}^{\mathbf{- 1}}\left(\boldsymbol{X}_{\boldsymbol{i} \boldsymbol{j}}-\overline{\boldsymbol{X}}_{\boldsymbol{i}}\right)
$$

sedemikian rupa sehingga $W_{i} \sim X_{k,(n-1)}^{2}$ ketika $\sum=\sum_{0}$, dan didefinisikan sebagai berikut.

$$
Y_{i}=(1-\lambda) Y_{i-1}+\lambda \phi^{-1}\left\{H_{k,(n-1)}\left(W_{i}\right)\right\}
$$

dengan $Y_{0}$ adalah titik awal dan sama dengan nol. $\lambda$ adalah smoothing parameter yang bernilai $0 \leq \lambda \leq 1$. Ketika variabilitas proses terkendali $\left(\sum=\sum_{0}\right)$ dan $Y_{0}=0$, Maka sebagai berikut.

$$
E\left(Y_{i}\right)=0
$$

dan

$$
\operatorname{Var}\left(Y_{i}\right)=\frac{\lambda\left[1-(1-\lambda)^{2 k}\right]}{2-\lambda}
$$

Sebuah statistik untuk memantau proses variabilitas didefinisikan sebagai berikut.

$$
V_{i}=\sqrt{\frac{2-\lambda}{\lambda\left[1-(1-\lambda)^{2 i}\right]}} Y_{i}
$$

Jelas bahwa $U_{i}$ dan $V_{i}$ adalah independent. Ketika $\mu=$ $\mu_{0}, \sum=\sum_{0}, Z_{0}=0$, dan $Y_{0}=0$, maka kedua $U_{i}$ dan $V_{i}$ mengikuti distribusi normal standar. Demikian, berdasarkan pada $U_{i}$ dan $V_{i}$, statistik baru untuk multivariat single chart akan didefinisikan sebagai berikut.

$$
M_{i}=\max \left\{\left|U_{i}\right| .\left|V_{i}\right|\right\}
$$

Karena $M_{i}$ adalah maksimum $U_{i}$ dan $V_{i}$, yaitu berdasarkan nilai absolut dari dua Statistik Multivariate Weighted Eksponential Statistik Moving Average (MEWMA). Maka hal itu wajar untuk menyebutkan grafik baru yaitu grafik Max-MEWMA [6]. Nilai besar $M_{i}$ untuk grafik Max-MEWMA menunjukkan bahwa proses vektor rata-rata dan/atau matrix kovarians telah bergeser dari $\mu_{0}$. Di sisi lain, nilai kecil $M_{i}$ menyiratkan bahwa proses vektor rata-rata dan variabilitas tetap dekat ke nilai nominalnya. Karena $M_{i}$ adalah non-negative, keadaan awal dari grafik kendali Max-MEWMA hanya didasarkan pada bagian atas batas kontrol (h). Jika $M_{i}>h$, grafik kendali terpicu alarm di luar kendali. Dimana $h>0$ adalah dipilih untuk mencapai ARL in-control tertentu.

i. Batas Kendali dari Max-MEWMA

Karena $U_{i}$ dan $V_{i}$ independen mengikuti distribusi normal standar. Diberikan bahwa $\mu=\mu_{0}$ dan $\sum=\sum_{0}$. In control CDF dari $M_{i}$ ditemukan sebagai berikut.

$$
\begin{gathered}
F\left(y: \mu_{0} \cdot \sum_{0}\right)=P\left(M_{i} \leq y \mid \mu=\mu_{0} \cdot \sum=\sum_{0}\right) \\
=P\left(\left|U_{i}\right| \leq y \cdot\left|V_{i}\right| \leq y\right) \\
=P\left(\left|U_{i}\right| \leq y\right) P\left(\left|V_{i}\right| \leq y\right) \\
=[2 \phi(y)-1]^{2} \quad y \geq 0
\end{gathered}
$$

Probability density function (PDF) terkendali dari $M_{i}$ adalah sebagai berikut.

$$
f\left(y: \mu_{0} \cdot \sum_{0}\right)=4 \phi(y)[2 \phi(y)-1]^{2}
$$
dengan $\phi($.$) adalah fungsi distribusi kumulatif normal$ standar Karena $M_{i}$ adalah non-negative. Grafik kendali Max-MEWMA hanya memerlukan batas kontrol atas (UCL). Maka dari itu, UCL adalah sebagai berikut.

$$
\begin{gathered}
U C L=E\left(M_{i}\right)+L \sqrt{\operatorname{Var}\left(M_{i}\right)} \\
=1,128379+0,602811 \mathrm{~L}
\end{gathered}
$$

dengan $\mathrm{L}$ adalah sebuah perkalian dan mengontrol perfoman dari grafik dengan $\lambda$ untuk nilai spesifikasi dari in control ARL dan $E\left(M_{i}\right)$ dan $\operatorname{Var}\left(M_{i}\right)$ diperoleh secara numerik [7]. 
ii. Penentuan Batas Atas

Penentual Batas Atas atau biasanya dikenal dengan batas kendali atas didapatkan melalui pendekatan dengan kriteria nilai Average Run Length atau ARL. Average Run Length (ARL) merupakan rata-rata jumlah titik yang harus diplotkan hingga didapatkan titik out of control pertama [8]. ARL untuk grafik kendali multivariat bisa sangat rumit jika perubahan matriks kovarians proses diperhatikan. Bahkan untuk grafik $|\mathrm{S}|$ yang banyak digunakan, tampak tidak ada yang mengevaluasi kinerja ARLnya. dihasilkan dari struktur kompleks dari matriks kovarians proses. Performa ARL untuk grafik Max-MEWMA diberikan sehubungan dengan nilai $\lambda, \mathrm{k}, \mathrm{n}$ yang berbeda. Pergeseran dalam proses rata-rata vektor dan perubahan dalam proses matriks kovarians. Untuk grafik Max-MEWMA tidak ada cara langsung untuk menghitung ARL. sehingga setiap nilai ARL diperoleh dengan menggunakan 10.000 simulasi [9]. Dalam penelitian tersebut, ARL terkendali yang digunakan sebesar 370.

\section{Diagram Ishikawa}

Diagram tulang ikan atau fishbone diagram adalah salah satu metode atau tools di dalam meningkatkan kualitas. Sering juga diagram ini disebut dengan diagram sebab-akibat atau cause-effect diagram. Diagram sebab akibat merupakan alat yang digunakan untuk mencari dan atau menganalisa penyebab timbulnya masalah sehingga memudahkan cara mengatasinya. Pada umumya faktorfaktor tersebut dikelompokkan kedalam enam faktor utama, yaitu $5 \mathrm{M}+1 \mathrm{E}$ yang terdiri dari material, man, methods, machine, measurement, dan environment [8].

\section{E. Kapabilitas Proses}

Pengendalian kualitas statistik hanya dapat memonitoring proses yang sedang berjalan, tetapi tidak dapat menganalisa secara kuantitatif, sehingga digunakan indeks kapabilitas proses untuk mengetahui suatu proses berjalan secara kapabel (nilai $\mathrm{Cp} \geq 1,33$ ) atau tidak. Proses dikatakan kapabel apabila dalam keadaan terkendali, memenuhi batas spesifikasi, serta tingkat presisi dan akurasi tinggi. Berdasarkan standar 3-sigma, suatu produk dikatakan mampu apabila memiliki indeks kapabilitas lebih dari 1,33. Jika proses dalam keadaan terkendali maka indeks yang digunakan adalah $C_{p}$ dan $C_{p k}$, sedangkan untuk proses yang tidak dalam keadaan terkendali maka indeks kemampuan proses yang digunakan adalah $P_{p}$ dan $P_{p k}$ [8]. Hal ini dikarenakan ketika proses dalam kondisi tidak terkendali, nilai varians tidak dapat ditaksir dari nilai sampel. $C_{p}$ dan $C_{p k}$ mempertimbangkan deviasi rata-rata dalam sub kelompok rasional. Perhitungan standar deviasi dengan menggunakan konstanta $\left(\hat{\sigma}=\frac{R}{d_{2}}\right)$, yang hanya memperhatikan faktor penyebab umum [8]. Sedangkan $P_{p}$ dan $P_{p k}$ mengatur penyimpangan berdasarkan data yang diteliti, dengan menghitung perhitungan standard deviasi total, yang mempertimbangkan faktor penyebab khusus dan penyebab umum Perhitungan indeks $C_{p}$ dan $C_{p k}$ serta $P_{p}$ dan $P_{p k}$ adalah sebagai berikutt.

$$
C_{p}=\frac{U S L-L S L}{6 \sigma}
$$

Dalam pengaplikasiannya, proses standar deviasi $\sigma$ hampir selalu tidak diketahui dan harus diestimasi. Untuk mengestimasi $\sigma$ digunakan standar deviasi sampel s dengan rumus sebagai berikut.

$$
\hat{C}_{p}=\frac{U S L-L S L}{6 \widehat{\sigma}}
$$

Untuk spesifikasi satu arah digunakan $C_{p u}$ dan $C_{p l}$ dengan rumus sebagai berikut.

$$
C_{p u}=\frac{U S L-\mu}{3 \sigma}, C_{p l}=\frac{\mu-L S L}{3 \sigma} .
$$

Indeks $C_{p}$ tidak memperhitungkan perbedaan rataan proses terhadap rataan spesifikasi. $C_{p k}$ merupakan perbaikan dari $C_{p}$, maka rumusnya adalah sebagai berikut.

$$
C_{p k}=\min \left(C_{p u}, C_{p l}\right)
$$

Jika $C_{p}=C_{p k}$, proses terpusat di rataan spesifikasi, dan tidak terpusat bila $C_{p}<C_{p k}$. Serupa dengan perhitungan $C_{p}$, kinerja tingkat $P_{p}$ mempunyai rumus sebagai berikut.

$$
\hat{P}_{p}=\frac{U S L-L S L}{6 s},
$$

di mana s adalah standar deviasi dari semua data yaitu

$$
s=\sqrt{\sum_{i=1}^{n} \frac{\left(x_{i}-\bar{x}\right)^{2}}{(n-1)}} .
$$

Untuk $P_{p k}$ dihitung dengan rumus sebagai berikut.

$$
P_{p k}=\min \left(\frac{U S L-\mu}{3 \widehat{\sigma}}, \frac{\mu-L S L}{3 \widehat{\sigma}}\right) .
$$

Perhitungan indeks $P_{p}$ dan $P_{p k}$ untuk data multivariat dapat dihitung dengan menggunakan persamaan sebagai berikut.

$$
\begin{gathered}
M P_{p k}=\sum_{k=1}^{p} W_{k} P_{p k}\left(X_{k}\right) \\
M P_{p}=\sum_{k=1}^{p} W_{k} P_{p}\left(X_{k}\right)
\end{gathered}
$$

$M P_{p k}$ dan $M P_{p k}$ berturut-turut merupakan bentuk $P_{p}$ dan $P_{p k}$ dalam keadaan multivariat dengan $W_{i}$ merupakan pembobot berdasarkan kepentingan dengan $\sum_{k=1}^{p} W_{k}=1$. Nilai pembobot $W_{i}$ disesuaikan dengan pembobot dari masing-masing karakteristik kualitas yang ditentukan oleh perusahaan, jika tidak ada maka pembobot dianggap sama [10].

\section{F. Baja}

Logam dan paduannya dikelompokkan menjadi dua berdasarkan komposisi kimia, yaitu logam-logam besi (ferrous) dan logam bukan besi (non-ferrous). Besi adalah logam dan paduan yang unsur utamanya adalah besi (Fe) sedangkan logam bukan besi merupakan bahan yang mengandung sedikit atau sama sekali tidak mengandung unsur besi (Fe). Klasifikasi logam dan paduan besi adalah besi tuang (cast iron), baja karbon (karbon steel), baja paduan (alloy steel), dan baja spesial (speciality steel). [11] menyatakan baja karbon adalah suatu baja yang mengandung karbon sampai maksimum 2\%. Baja karbon dapat dibagi atas tiga bagian, antara lain baja karbon rendah, baja karbon sedang, dan baja karbon tinggi.

\section{G. Perusahaan PT Krakatau Steel}

PT Krakatau Steel merupakan perusahaan yang berbentuk persero dan merupakan pabrik baja terbesar di Indonesia. PT Krakatau Steel resmi berdiri sejak tanggal 31 Agustus 1970 yang mengolah bijih besi dalam bentuk setengah jadi maupun bahan jadi untuk dipasarkan kepada konsumen. Perusahaan ini memiliki enam unit produksi, yaitu pabrik besi spons, pabrik baja slab, pabrik baja lembaran panas, pabrik pengerolan baja lembaran dingin, pabrik billet baja, dan pabrik batang kawat.

Billet Baja merupakan salah satu jenis baja yang kandungan unsur utamanya tediri dari 3 unsur kimia sekaligus. Proses pabrik Billet Baja di PT Krakatau Steel terbagi dalam beberapa bagian sesuai dengan proses pembuatan yang ada dan proses-proses tersebut meliputi proses peleburan, proses ladle furnance, dan proses 
pengecoran. Bahan baku yang digunakan dalam proses berupa Besi Spons (Sponge Iron), Besi Tua (Scrap), Kapur Bakar (Lime Stone), dan Unsur-unsur paduan. Proses produksi di pabrik billet baja di PT Krakatau Steel terbagi menjadi 4 tahapan

\section{METODOLOGI PENELITIAN}

\section{A. Sumber Data}

Data yang digunakan adalah data sekunder yang diperoleh dari departemen Quality Control dan Quality Assurance PT Krakatau Steel pada bulan Oktober 2017 sampai April 2018. Data berukuran 4 subgrup. Keterangan variabel yang digunakan pada penelitian disajikan pada Tabel 1.

\begin{tabular}{ccc}
\multicolumn{3}{c}{ Tabel 1. Variabel Pengamatan } \\
\hline Variabel & Deskripsi & Batas Spesifikasi (\%) \\
\hline$X_{1}$ & Karbon (C) & $0,000-0,100$ \\
$X_{2}$ & Silicon (Si) & $0,000-0,100$ \\
$X_{3}$ & Mangan (Mn) & $0,000-0,600$ \\
\hline
\end{tabular}

\section{B. Struktur Data}

Tabel 2. merupakan struktur data produk billet baja KS1008.

Tabel 2. Struktur Data

\begin{tabular}{|c|c|c|c|c|c|}
\hline \multirow[t]{2}{*}{ Fase } & \multirow{2}{*}{$\begin{array}{l}\text { Observasi } \\
\text { ke- (Hari) }\end{array}$} & \multirow{2}{*}{$\begin{array}{l}\text { Subgrup } \\
\text { (Unit) }\end{array}$} & \multicolumn{3}{|c|}{$\begin{array}{l}\text { Karakteristik } \\
\text { Kualitas (\%) }\end{array}$} \\
\hline & & & $\mathbf{X}_{1}$ & $\mathbf{X}_{2}$ & $\mathbf{X}_{3}$ \\
\hline \multirow{7}{*}{1} & & 1 & $x_{1,1}$ & $x_{1,2}$ & $x_{1,3}$ \\
\hline & & $\vdots$ & $\vdots$ & $\vdots$ & $\vdots$ \\
\hline & 1 & 4 & $x_{4,1}$ & $x_{4,2}$ & $x_{4,3}$ \\
\hline & $\vdots$ & $\vdots$ & $\vdots$ & $\vdots$ & $\vdots$ \\
\hline & 120 & 1 & $x_{356,1}$ & $x_{356,2}$ & $x_{356,3}$ \\
\hline & & $\vdots$ & $\vdots$ & $\vdots$ & $\vdots$ \\
\hline & & 4 & $x_{480,1}$ & $x_{480,2}$ & $x_{480,3}$ \\
\hline \multirow{7}{*}{2} & & 1 & $x_{481,1}$ & $x_{481,2}$ & $x_{481,3}$ \\
\hline & & $\vdots$ & $\vdots$ & $\vdots$ & $\vdots$ \\
\hline & 121 & 4 & $x_{484,1}$ & $x_{484,2}$ & $x_{584,3}$ \\
\hline & $\vdots$ & $\vdots$ & $\vdots$ & $\vdots$ & $\vdots$ \\
\hline & 210 & 1 & $x_{836,1}$ & $x_{836,2}$ & $x_{836,3}$ \\
\hline & & $\vdots$ & $\vdots$ & $\vdots$ & $\vdots$ \\
\hline & & 4 & $x_{840,1}$ & $x_{840,2}$ & $x_{840,3}$ \\
\hline
\end{tabular}

Keterangan:

$x_{i, k}=$ nilai untuk karakteristik kualitas ke-k pada observasi $\mathrm{ke}-\mathrm{i}, \mathrm{i}=1,2, \ldots, \mathrm{t}$ dan $\mathrm{k}=1,2,3$ dengan $\mathrm{X}_{1}$ merupakan karbon (C), $\mathrm{X}_{2}$ merupakan silicon ( $\mathrm{Si}$ ) dan $\mathrm{X}_{3}$ merupakan mangan $(\mathrm{Mn})$. Satuan dari ketiga variabel tersebut adalah persen berat $(\%)$.

C. Langkah Analisis

Metode analisis yang digunakan dalam penelitian adalah sebagai berikut.

1. Mendeskriptifkan data pada masing-masing variabel dengan statistika deskriptif.

2. Melakukan pengujian dependensi variabel dengan menggunakan uji Bartlett pada variabel karbon (C), silicon ( $\mathrm{Si}$ ) dan mangan (Mn).

3. Melakukan uji asumsi normal multivariat pada variabel karbon $(\mathrm{C})$, silicon $(\mathrm{Si})$ dan mangan $(\mathrm{Mn})$.

4. Membuat grafik kendali Max-MEWMA.

5. Identifikasi titik out of control.

6. Menghitung kapabilitas proses.
7. Kesimpulan dan saran.

\section{HASIL DAN PEMBAHASAN}

\section{A. Karakteristik Kualitas}

Billet baja KS1008 dikatakan baik jika variabel karakteristik kualitasnya berada dalam batas spesifikasi yang telah ditentukan perusahaan. Untuk mengetahui gambaran umum tentang masing-masing karakteristik kualitas periode bulan Oktober 2017 hingga bulan April 2018 pada billet baja KS1008.

Maka diberikan deskripsi kualitas yang dapat digambarkan melalui Tabel 3 sebagai berikut.

Tabel 3. Deskripsi Karakteristik Kualitas Billet Baja KS1008 Fase I

\begin{tabular}{lcccc}
\hline Variabel & Rata-Rata & Varians & Minimum & Maksimum \\
\hline Karbon & 0,0774 & 0,000184 & 0,048 & 0,176 \\
Silicon & 0,0734 & 0,000251 & 0,02 & 0,174 \\
Mangan & 0,5043 & 0,00143 & 0,396 & 0,682 \\
\hline
\end{tabular}

Berdasarkan Tabel 3, dapat diketahui data fase I secara umum rata-rata kandungan karbon $(\mathrm{C})$, silicon $(\mathrm{Si})$ dan mangan $(\mathrm{Mn})$ pada fase 1 berada dalam batas spesifikasi perusahaan. Namun, beberapa titik pengamatan pada ketiga variabel masih berada diluar batas spesifikasi yang ditentukan. Hal ini dapat dilihat melalui maksimum masingmasing variabel. Ketiga nilai maksimum tersebut lebih tinggi jika dibandingkan dengan batas spesifikasi atas yang dimiliki perusahaan, yaitu sebesar $0,1 \%$ untuk variabel karbon (C) dan silicon ( $\mathrm{Si}$ ) sedangkan $0,6 \%$ untuk variabel mangan (Mn). Diketahui bahwa nilai varians terbesar adalah pada variabel mangan, yaitu sebesar 0,00143\%. Nilai ini dapat dikatakan cukup besar jika dibandingkan dengan varians pada variabel lainnya. Hal ini menunjukkan bahwa nilai persentase pada mangan periode bulan Oktober hingga bulan Januari 2018 cenderung heterogen, karena jarak antar data relatif besar.

Selanjutnya adalah karakteristik kualitas fase II, yaitu periode bulan Februari hingga bulan April 2018 pada billet baja KS1008 maka diberikan deskripsi kualitas pada Tabel 4 sebagai berikut.

Tabel 4. Deskripsi Karakteristik Kualitas Billet Baja KS1008 Fase II

\begin{tabular}{lcccc}
\hline Variabel & Rata-Rata & Varians & Minimum & Maksimum \\
\hline Karbon & 0,0737 & 0,000184 & 0,047 & 0,212 \\
Silicon & 0,0735 & 0,000264 & 0,010 & 0,173 \\
Mangan & 0,5285 & 0,00118 & 0,432 & 0,60 \\
\hline
\end{tabular}

Berdasarkan Tabel 4, diatas dapat diketahui data fase II secara umum rata-rata kandungan karbon (C), silicon ( $\mathrm{Si}$ ) dan mangan (Mn) pada fase II tetap berada dalam batas spesifikasi perusahaan. Namun, beberapa titik pengamatan pada ketiga variabel masih berada diluar batas spesifikasi yang ditentukan. Hal ini dapat dilihat melalui maksimum masing-masing variabel. Nilai maksimum variabel karbon dan silicon lebih tinggi jika dibandingkan dengan batas spesifikasi atas yang dimiliki perusahaan, yaitu sebesar $0,1 \%$ untuk variabel karbon $(\mathrm{C})$ dan silicon (Si). Diketahui bahwa nilai varians terbesar masih pada variabel mangan, yaitu sebesar $0,00118 \%$. Nilai ini dapat dikatakan cukup besar jika dibandingkan dengan varians pada variabel lainnya. Hal ini menunjukkan bahwa nilai persentase pada mangan (Mn) periode bulan Februari hingga bulan April 2018 masih paling cenderung heterogen, karena jarak antar data relatif besar.

\section{B. Pemeriksaan Dependensi Antar Variabel}

Sebelum dilakukan pengendalian kualitas pada billet baja KS1008 menggunakan grafik kendali Max-MEWMA, 
variabel karakteristik kualitas billet baja KS1008 harus memenuhi asumsi dependensi. Maka digunakan uji KMO dan Bartlett. Didapatkan bahwa nilai KMO lebih 0,5 yakni sebesar 0,508 sehingga data dapat difaktorkan dan nilai Chisquare sesuai persamaan (1) yaitu sebesar 61,438. Nilai ini lebih besar dari nilai Chi-Square tabel atau sebesar 7,815. Sehingga dapat disimpulkan bahwa ketiga variabel karakteristik kualitas billet baja KS1008 saling dependen. Selain itu, jika ditinjau dari $P$-value. Dapat diketahui bahwa $P$-value yang didapatkan adalah sebesar 0,000 . Karena $P$ value kurang dari taraf signifikansi sebesar $5 \%$, maka dapat disimpulkan pula bahwa ketiga variabel karakteristik kualitas billet baja KS1008 saling dependen. Hal ini memperkuat teori bahwa ketiga variabel karakteristik kualitas dalam penelitian ini saling berhubungan antar satu sama lain.

\section{Pemeriksaan Distribusi Normal Multivariat}

Pemeriksaan distribusi normal multivariat dilakukan pada ketiga variabel karakteristik kualitas utama billet baja KS1008, yaitu variabel karbon (C), silicon (Si) dan mangan (Mn). Uji distribusi normal multivariat menggunakan uji Shapiro-Wilk. Didapatkan p-value dari uji Shapiro-Wilk pada data kualitas billet baja KS1008 bernilai kurang dari nilai alpha 5\% yakni 0,000 sehingga menghasilkan keputusan tolak $\mathrm{H}_{0}$, yang artinya data kualitas billet baja KS1008 tersebut tidak berdistribusi normal multivariate. Namun dalam teori MEWMA menunjukkan bahwa robust terhadap hal itu sehingga tetap dapat digunakan pada grafik kendali Max-MEWMA

\section{Grafik Kendali Max-MEWMA}

Pengendalian kualitas pada rata-rata dan varians billet baja KS1008 dilakukan dengan menggunakan grafik kendali maximum multivariate weight moving average atau Max-MEWMA dengan menggunakan nilai maksimal dari jumlah nilai rata-rata dan varians yang dihitung. Selama titik pengamatan terletak di bawah interval keputusan $(h)$, proses dianggap dalam keadaan terkendali. Sebaliknya jika berada di atas interval keputusan $(h)$, maka proses dikatakan tidak terkendali. Statistik $M_{i}$ akan besar ketika vektor mean proses jauh dari nilai $\boldsymbol{\mu}_{\mathbf{0}}$ atau ketika variabilitas proses jauh dari nilai $\Sigma$. Nilai $M_{i}$ yang kecil menunjukan bahwa proses berada dalam keadaan terkendali secara statistik. Karena $M_{i}$ $\geq 0$, maka hanya digunakan batas kontrol atas atau $h$. Batas kontrol atas atau nilai interval keputusan $(h)$ didapatkan dengan melakukan simulasi pada 10000 bangkitan data random yang memiliki nilai rata-rata dan matriks kovarians dari data karakteristik kualitas billet baja KS1008 pada fase 1. Penentuan dilakukan dengan cara yaitu sebagai berikut.

1. Penentuan Interval Keputusan $(h)$

Interval keputusan $(h)$ atau biasanya dikenal dengan batas kendali atas didapatkan melalui simulasi dengan nilai ARL sebesar 370 dengan menggunakan $\alpha$ sebesar 0,0027 . Setelah dilakukan simulasi seperti yang telah diuraikan pada bab II, maka didapatkan hasil yaitu sebagai berikut.

Berdasarkan Tabel 5, dapat diketahui bahwa semakin tinggi nilai interval keputusan $(h)$ maka nilai ARL cenderung semakin tinggi, begitu juga sebaliknya. Dengan menggunakan interval keputusan $(h)$ sebesar 3,0099, didapatkan nilai average run length atau ARL sebesar 370,84. Sehingga interval keputusan $(h)$ yang akan digunakan pada pengendalian kualitas billet baja KS1008 menggunakan grafik kendali Max-MEWMA adalah sebesar 3,0099 .

Tabel 5. Hasil ARL menggunakan simulasi

\begin{tabular}{cc}
\hline Interval Keputusan $(\boldsymbol{h})$ & Average Run Length (ARL) \\
\hline 3,00 & 369,43 \\
3,0099 & 370,84 \\
3,01 & 371,04 \\
3,019 & 371,64 \\
3,02 & 372,09 \\
\hline
\end{tabular}

2. Pengendalian Kualitas Billet Baja Fase I

Pengendalian kualitas billet baja KS1008 fase 1 dilakukan untuk memonitoring kestabilan proses produksi billet baja KS1008. Setelah dilakukan simulasi dan didapatkan nilai interval keputusan $(h)$ sebesar 3,0099 dengan nilai ARL yang didapatkan yaitu sebesar 370,84, selanjutnya dilakukan pengendalian pada data karakteristik kualitas billet baja KS1008 fase 1. Data yang digunakan untuk pengendalian kualitas menggunakan grafik kendali Max-MEWMA pada fase 1 merupakan data kualitas billet baja KS1008 pada bulan Oktober 2017 hingga Januari 2018 sehingga didapatkan hasil sebagai berikut.

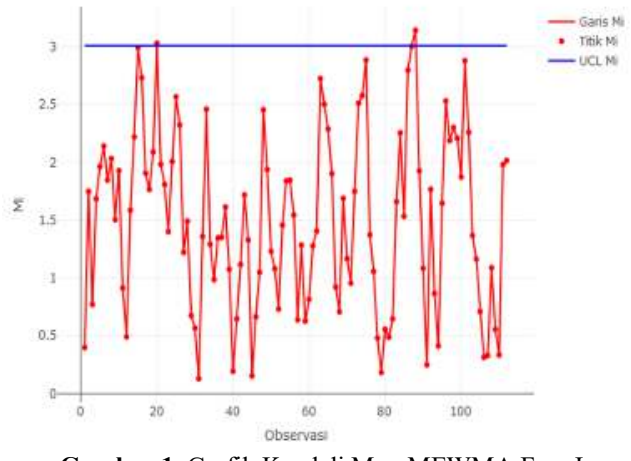

Gambar 1. Grafik Kendali Max-MEWMA Fase I

Berdasarkan Gambar 1, dapat dilihat pada grafik kendali Max-MEWMA kualitas billet baja KS1008 fase I. Dimana sumbu horizontal menunjukkan banyaknya pengamatan pada fase I dan sumbu vertikal menunjukkan nilai $M_{i}$ yang di plot setiap titik. Kemudian, garis biru merupakan UCL atau interval keputusan dengan interval keputusan $(h)$ sebesar 3,0099 sehingga menandakan bahwa belum terkendali secara statistik. Hal ini dikarenakan terdapat titik observasi $\left(M_{i}\right)$ tersebut grafik kendali MaxMEWMA disimbolkan $M_{i}$ yang berarti nilai $M_{25}, M_{26}, M_{29}$, $M_{30}, M_{53}, M_{94}, M_{108}$ dan $M_{110} \geq h$, yaitu 3,0099. Hal ini menunjukan adanya pergeseran mean proses pada titik $M_{29}$, $M_{30}, M_{94}, M_{108}$ dan $M_{110}$ dan pergeseran varians proses pada titik $M_{25}, M_{26}$ dan $M_{53}$. Berdasarkan hasil brainstorming dengan perusahaan, pada fase I pada 8 titik out of control disebabkan oleh adalah adanya indikasi terjadi kebocoran pada panel pendingin, terjadi reaksi kimia pada variabel penelitian, elektrode pada saat penyambungan kurang kencang dan komponen mesin EAF dimana bata tahan api mengalami penyusutan volume.

Setelah diketahui penyebab pengamatan yang out of control maka pengamatan yang out of control dihilangkan dari perhitungan untuk mendapatkan proses produksi yang terkontrol. Hasil setelah pengamatan out of control dihilangkan dari perhitungan dapat dilihat pada Gambar 4.2 sebagai berikut. 


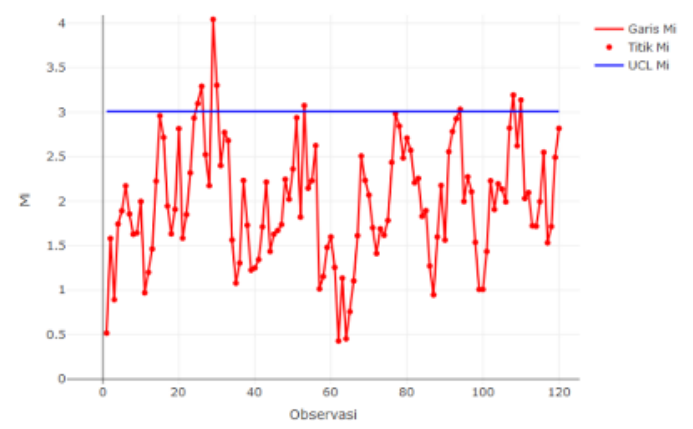

Gambar 2. Grafik Kendali Max-MEWMA Fase I (1)

Berdasarkan grafik kendali Max-MEWMA diatas, dapat diketahui bahwa billet baja KS1008 pada fase I masih belum terkendali secara statistik. Hal ini dikarenakan masih terdapat 2 titik observasi $\left(M_{i}\right)$ yang berada di atas interval keputusan $(h)$, yaitu pada titik observasi $\left(M_{i}\right)$ ke-20 dan 88 . Sama seperti grafik kendali Max-MEWMA sebelumnya, titik observasi $\left(M_{i}\right)$ ke-20, dan 88 grafik kendali MaxMEWMA disimbolkan dengan $M_{20}$, dan $M_{88} \geq h$, yaitu 3,03 dan 3,14> 3,0099, yang menunjukan adanya pergeseran proses mean proses pada titik pada titik $M_{20}$, dan $M_{88}$. Berdasarkan hasil brainstorming dengan perusahaan, pada fase I pada dua titik out of control disebabkan oleh adalah adanya indikasi mesin EAF terjadi shutdown secara tibatiba dan terjadi reaksi kimia pada proses produksi.

Setelah diketahui penyebab pengamatan yang out of control maka pengamatan yang out of control dihilangkan dari perhitungan untuk mendapatkan proses produksi yang terkontrol. Hasil setelah pengamatan out of control dihilangkan dari perhitungan dapat ditujukan pada Gambar 4.3. Dan Iterasi pada grafik kendali Max-MEWMA ini dilampirkan dalam lampiran.

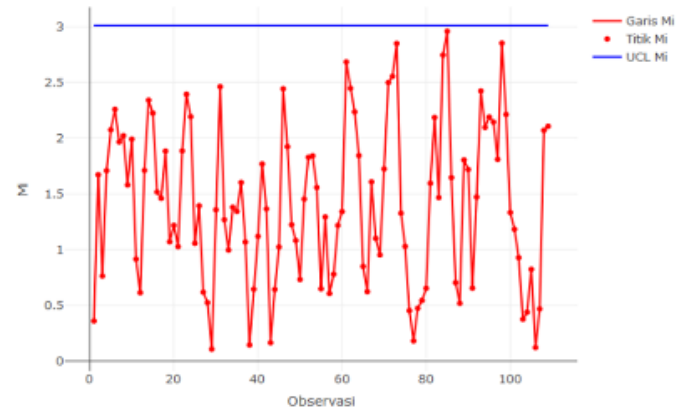

Gambar 3. Grafik Kendali Max-MEWMA Fase I (Final)

Setelah dilakukan perbaikan grafik kendali MaxMEWMA sebanyak 3 kali perbaikan, didapatkan grafik kendali Max-MEWMA seperti Gambar 3 diatas. Berdasarkan grafik kendali Max-MEWMA diatas, dapat diketahui bahwa dengan menggunakan batas interval $(h)$ 3,0099 , semua titik observasi berada di dalam batas interval (h) atau di bawah batas kendali atas. Hal ini mengindikasikan bahwa tidak terjadi pergeseran baik pada rata-rata maupun varians proses. Sehingga dapat disimpulkan bahwa kualitas billet baja KS1008 fase I menggunakan grafik kendali Max-MEWMA telah terkendali secara statistik. Penelitian selanjutnya dilanjutkan dengan melakukan pengendalian kualitas billet baja KS1008 fase II.

3. Pengendalian Kualitas Billet Baja Fase II

Pengendalian kualitas billet baja KS1008 fase II dilakukan untuk memonitoring kestabilan proses produksi billet baja KS1008. Data yang digunakan untuk pengendalian kualitas menggunakan peta kendali MaxMEWMA pada fase II merupakan data kualitas billet baja KS1008 pada bulan Februari hingga April 2018 yaitu sebanyak 90 data dengan 4 subgroup. Pengendalian dilakukan menggunakan batas kendali atau batas interval (h) yang didapatkan dari grafik kendali Max-MEWMA fase I dengan parameter mean dan varians dari data fase I. Sehingga didapatkan grafik kendali Max-MEWMA fase II sebagai berikut.

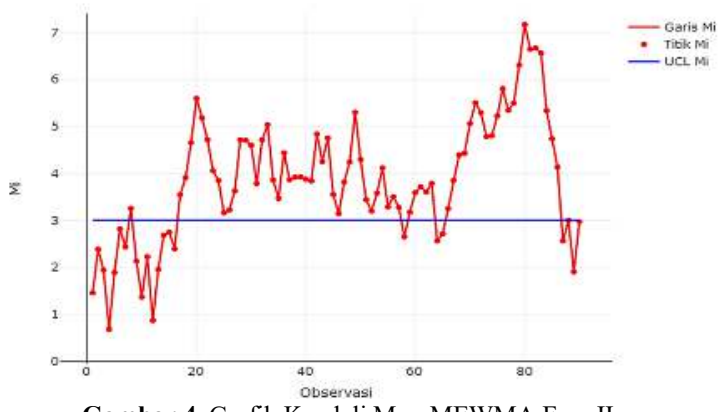

Gambar 4. Grafik Kendali Max-MEWMA Fase II

Grafik kendali Max-MEWMA pada Gambar 4, menunjukkan bahwa proses produksi billet baja KS1008 fase II dengan interval keputusan $(h)$ sebesar 3,0092 tidak terkendali secara statistik. Hal ini dikarenakan terdapat titik observasi $\left(M_{i}\right)$ yang berada di atas interval keputusan $(h)$. Hal ini menunjukan adanya pergeseran baik pada mean maupun varians proses.

Berdasarkan hasil brainstorming dengan perusahaan, pada fase II pada titik pengamatan yang out of control disebabkan oleh adalah adanya indikasi pada tanggal 20 bulan Februari terjadi problem pada mesin produksi yang mengakibatkan masalah yang serius pada proses produksi dan terjadi masalah pada laboratorium pada bulan maret serta kebocoran pada mesin EAF yang disebabkan terjadinya penyusutan volume pada bata tahan api pada akhir-akhir proses produksi pada bulan April.

\section{E. Identifikasi Out of Control}

Berdasarkan pengendalian kualitas yang dilakukan di fase dua, terdapat titik-titik pengamatan yang diplot diluar batas kendali atas sehingga menyebabkan proses produksi billet baja KS1008 tidak terkendali secara statistik. Oleh karena itu, untuk mengetahui penyebab titik pengamatan berada diluar batas kendali atas, perlu dilakukan identifikasi variabel penyebab out of control secara multivariat dengan kombinasi 2 variabel dari 3 variabel yang digunakan dengan total kombinasi sebanyak 3 dan menggunakan diagram ishikawa. Berikut merupakan identifikasi yang dilakukan.

\section{Identifikasi Variabel Penyebab Out of Control}

Evaluasi variabel yang diduga sebagai penyebab out of control pada pengendalian kualitas statistik secara multivariat diperlukan agar perusahaan dapat melakukan perbaikan secara lebih sistematis dengan memperhatikan variabel apa yang memiliki kontribusi terbesar dalam menyebabkan out of control pada proses. Evaluasi dilakukan dengan melakukan monitoring stabilitas proses secara multivariat dengan menggunakan kombinasi 2 variabel secara bergantian. Berikut merupakan kombinasi 2 variabel yang dilakukan.

a. Kombinasi Karbon dan Silicon

Evaluasi pertama dilakukan dengan monitoring grafik kendali Max-MEWMA antara karbon dan silicon tanpa 
melibatkan variabel mangan. Dengan menggunakan batas kendali yang telah ditetapkan menggunakan simulasi, yakni sebesar 3,1505, didapatkan hasil proses produksi dari dua variabel adalah sebagai berikut.

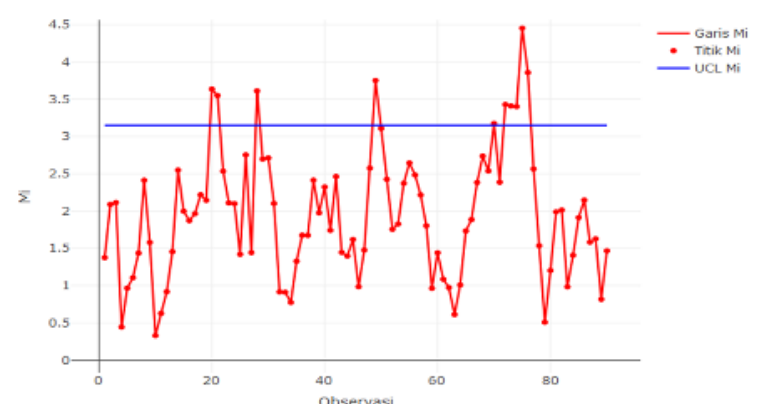

Gambar 5. Identifikasi Out of Control Karbon-Silicon

Gambar 5 merupakan grafik kendali Max-MEWMA antara variabel karbon dan silicon. Dengan menggunakan batas kendali sebesar 3,1505, terdapat 10 titik pengamatan yang berada diluar batas kendali atas. Titik tersebut juga keluar pada pengamatan grafik kendali Max-MEWMA pada fase II dengan menggunakan 3 variabel. Titik pengamatan yang berada diluar batas kendali atas dengan keterangan menyebabkan pergeseran vektor mean proses antara lain $M_{20}, M_{21}, M_{49}, M_{72}, M_{73}, M_{74}, M_{75}$, dan $M_{76}$. Sedangkan titik pengamatan yang berada diluar batas kendali atas yang menyebabkan pergeseran variabilitas proses yakni $M_{28}$.

b. Kombinasi Karbon dan Mangan

Evaluasi kedua dilakukan dengan monitoring grafik kendali Max-MEWMA antara karbon dan mangan tanpa melibatkan variabel silicon. Dengan menggunakan batas kendali yang telah ditetapkan menggunakan simulasi, yakni sebesar 3,2, didapatkan hasil proses produksi sebagai berikut.

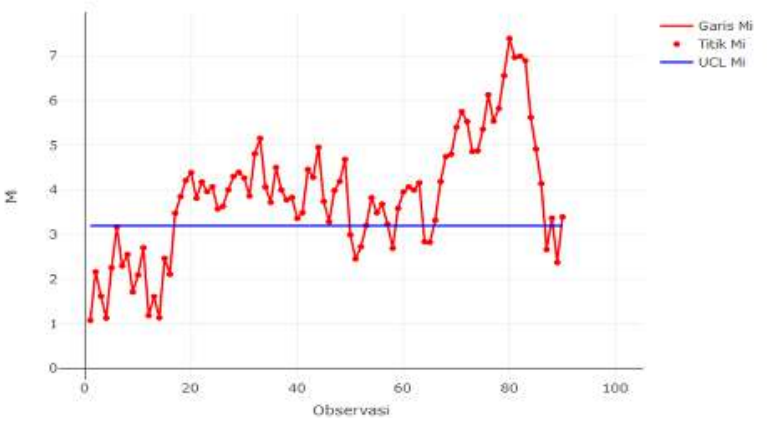

Gambar 6. Identifikasi Out of Control Karbon-Mangan

Gambar 6. merupakan grafik kendali Max-MEWMA antara karbon dan mangan. Berdasarkan Gambar 6 terlihat bahwa tanpa variabel silicon terdapat 64 titik pengamatan yang out of control yang sama dengan titik out of control pada grafik kendali Max-MEWMA fase II dengan menggunakan 3 variabel. Namun, terdapat 2 pengamatan yang out of control yang disebabkan oleh variabel lain. Sehingga, menunjukan adanya pergeseran baik pada mean maupun varians proses.

\section{c. Kombinasi Silicon dan Mangan}

Evaluasi kedua dilakukan dengan monitoring grafik kendali Max-MEWMA antara silicon dan mangan tanpa melibatkan variabel karbon. Dengan menggunakan batas kendali yang telah ditetapkan menggunakan simulasi, yakni sebesar 3,179, didapatkan hasil proses produksi sebagai berikut.

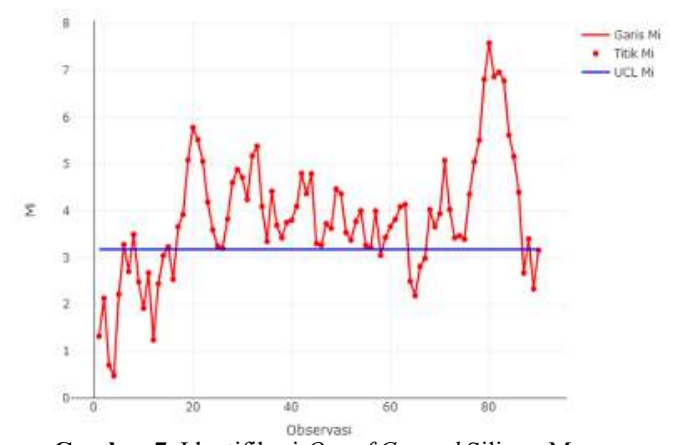

Gambar 7. Identifikasi Out of Control Silicon-Mangan

Gambar 7 merupakan grafik kendali Max-MEWMA antara silicon dan mangan. Apabila dilakukan pengendalian pada kombinasi kedua variabel tersebut terlihat bahwa tanpa variabel karbon terdapat 66 titik pengamatan out of control yang sama dengan titik out of control pada grafik kendali Max-MEWMA fase II dengan menggunakan 3 variabel. Namun, terdapat 3 pengamatan yang out of control yang disebabkan oleh variabel lain. Hal tersebut menunjukkan bahwa terjadi pergeseran baik mean dan variabilitas proses.

Sehingga, setelah dilakukan identifikasi variabel penyebab out of control dengan cara mengombinasi 2 variabel secara bergantian didapatkan hasil bahwa karbon (C), silicon ( $\mathrm{Si}$ ) dan mangan (Mn) menyebabkan titik out of control pada fase II. Akan tetapi dari 3 variabel tersebut disimpulkan bahwa variabel mangan (Mn) merupakan variabel yang berkontribusi besar dalam menyebabkan pengamatan out of control pada penelitian ini. Karena, jika dikombinasikan dengan karbon dan silicon (Si) menyebabkan titik out of control yang banyak dan titik tersebut merupakan titik pengamatan yang out of control pada grafik kendali Max-MEWMA fase II dengan menggunakan 3 variabel. Setelah berdiskusi dengan perusahaan, hasil tersebut linear dengan hasil analisis identifikasi variabel out of control yang dilakukan, bahwa variabel yang berpotensi besar menyebabkan gangguan adalah Mangan (Mn).

\section{Identifikasi menggunakan Diagram Ishikawa}

Setelah melakukan brainstorming dengan pihak perusahaan, pada faktor environment atau lingkungan sekitar pabrik disebabkan oleh debu dan radiasi panas. Sehingga, menyebabkan hal-hal yang tidak diinginkan terhadap karbon, silicon, dan mangan. Kemudian, terpapar oleh bising nya sekitar pabrik yang dapat berakibat fatal atau mungkin billet baja tidak sesuai dengan spesifikasi yang telah ditetapkan oleh perusahaan. Faktor selanjutnya adalah faktor personnel atau faktor yang berasal dari manusia yaitu operator melakukan loss control indicator dalam proses produksi sehinggal menimbulkan kesalahan pada proses dan operator salah mengatur proses produksi. Kemudian, pemotongan tidak sesuai standar dan cleaning yang tidak continuous yang dilakukan oleh pegawai sehingga menimbulkan produk billet baja KS1008 tidak sesuai.

Faktor berikutnya yang menyebabkan adalah faktor methods, terdapat operator yang salah mengatur proses produksi sehingga dapat berakibat fatal. Selain itu, formula pada saat peleburan billet baja yang tidak sesuai dengan spesifikasi yang telah ditetapkan oleh perusahaan. Kemudian faktor measurement antara lain casting speed pada proses produksi tidak sesuai dan pendinginan tidak sesuai ketentuan yang menyebabkan proses produksi billet baja bermasalah. Selanjutnya pada faktor material, dimana 
terjadinya reaksi kimia antara variabel utama dengan variabel oksigen yang muncul pada proses produksi sehingga menyebabkan terjadinya oksidasi. Apabila hal tersebut terjadi maka akan menyebabkan perubahan produksi billet baja yang tidak sesuai dengan spesifikasi yang ditetapkan oleh perusahaan. Dan kemudian faktor machine diketahui bahwa terjadi kebocoran pada panel pendingin dan komponen mesin EAF dimana bata tahan api mengalami penyusutan volume sehingga menjadi tipis. Selain itu, mesin EAF tiba-tiba mengalami shutdown pada proses produksi yang sedang berlangsung.

\section{F. $\quad$ Kapabilitas Proses}

Berdasarkan pengendalian kualitas fase dua didapatkan keadaan proses tidak terkendali secara statistik. Setelah dilakukan perhitungan, didapatkan nilai $M P_{p}$ dan $M P_{p k}$ sebesar 1,5 dan 0,489. Maka, kinerja proses secara potensial sudah baik dan telah mencapai ragam atau sebaran yang diinginkan, sedangkan dengan menggunakan indeks $M P_{p k}$ secara multivariat proses memiliki aktual yang rendah sehingga kinerja proses produksi billet baja KS1008 di PT Krakatau Steel tidak kapabel.

\section{KESIMPULAN DAN SARAN}

\section{A. Kesimpulan}

Pengendalian proses yang dilakukan pada penelitian ini menggunakan grafik kendali Max-MEWMA dengan menerapkan fase satu dan fase dua. Pada fase satu grafik kendali telah terkendali secara statistik pada iterasi 3 setelah menghilangkan 11 pengamatan. Pada fase dua dengan menerapkan batas kendali atas pada fase satu didapatkan hasil bahwa grafik kendali Max-MEWMA belum terkendali secara statistik dimana dapat diartikan bahwa proses produksi billet baja KS1008 belum terkendali secara statistik. Pengamatan yang berada diluar batas kendali menunjukkan bahwa terdapat beberapa billet baja KS1008 yang belum sesuai dengan spesifikasi yang diinginkan perusahaan.

Identifikasi variabel penyebab out of control didapatkan hasil bahwa karbon (C), silicon ( $\mathrm{Si}$ ) dan mangan (Mn) menyebabkan titik out of control pada fase II. Akan tetapi dari 3 variabel tersebut disimpulkan bahwa variabel mangan (Mn) merupakan variabel yang berkontribusi besar dalam menyebabkan pengamatan out of control pada penelitian ini. Karena, jika di kombinasikan dengan karbon dan silicon ( $\mathrm{Si}$ ) menyebabkan titik out of control yang banyak dan titik tersebut merupakan titik pengamatan yang out of control pada grafik kendali Max-MEWMA fase II dengan menggunakan 3 variabel. Dan diperkuat dengan 6 faktor penyebab utama proses produksi billet baja KS1008 tidak terkendali secara statistik. Kemudian, dalam mengukur kinerja proses produksi dari billet baja KS1008 digunakan kapabilitas secara multivariat. Hasil yang didapatkan secara multivariat adalah kinerja proses produksi billet baja KS1008 potensial sudah baik dan telah mencapai ragam atau sebaran yang diinginkan Perusahaan namun memiliki aktual yang rendah sehingga kinerja proses produksi billet baja di PT Krakatau Steel tidak kapabel.

\section{B. Saran}

Saran yang dapat diberikan kepada pihak PT. Krakatau Steel adalah analisis dengan menggunakan metode grafik kendali dapat menjadi pilihan untuk mengevaluasi proses produksi dari billet baja KS1008. Kemudian didapatkan hasil bahwa variabel yang berkontribusi menyebabkan pengamatan out of control adalah mangan, sehingga perusahaan sebaiknya lebih waspada. Selain itu, faktor lain penyebab keluarnya titik pengamatan dari batas kendali atas berasal dari sumber daya manusia salah satunya adalah operator. Sebaiknya operator yang bertugas pada bagian produksi diberikan pelatihan dahulu lalu baru diwenangkan bertugas, agar tidak terjadi kekeliruan dalam mengatur proses produksi dari billet baja KS1008 dan diharapkan perusahaan memperhatikan lingkungan di sekitar perusahaan agar proses produksi berjalan lancar.

\section{DAFTAR PUSTAKA}

[1] J. Alisjahbana, "Evaluasi Pengendalian Kualitas Total Produk Pakaian," Jurnal Ventura, pp. Vol. 8, No. 1, 2005.

[2] K. Budinski, Engineering Materials Properties and Selection sixth Edition, New Jersey: Prentice Hall, 2000.

[3] F. Morrison, Multivariate Statistical Methods., Fourth Edition penyunt., The Wharton School University of Pennsylvania, 1990.

[4] M. Razali dan Y. Wah, "Power Comparisons of SaphiroWilks, Kolmogorov-Smirnov, Liliefors, and AndersonDarling Test," Journal of Statistical Modeling and Analysis, pp. II(1), 21-23, 2011.

[5] J. Alva dan E. Estrada, "A Generalization of Shapiro-Wilk's Test for Multivariate-Normality," Communication in Statistics-Theory and Methods, pp. 38(11), 1870-1883, 2009.

[6] G. Chen, S. W. Cheng dan H. Xie, "A New Multivariate Control Chart For Monitoring Both Location and Dispersion," Communications in Statistics-Simulation and Computation, pp. 34(1), pp. 203-217, 2005.

[7] S. E. Ridgon dan C. W. Champ, Multivariate Geometric Moving Average Charts, San Fransisco: Joint Statistical Meetings, 1987.

[8] D. C. Montgomery, Introduction to Statistical Quality Control, New Jersey: John Wiley Sons, 2013.

[9] J. M. Lowry, A Multivariate Exponentially Weighted Moving Average Control Chart, USA: University of South Louisiana, 1989.

[10] S. Raissi, "Multivariate Process Capability Indices on the Presence of priority for Quality Characteristics," Journal of Industrial Engineering International, Vol 5, No 19, pp. 2736, 2009.

[11] F. Rusmardi, "Analisa Persentase Kandungan Karbon pada Logam Baja,” Teknik Mesin, pp. 35-43, 2006. 